УAK 340.1

ББК 67.0

DOI 10.22394/1682-2358-2019-2-133-138

E.Yu. Yanovich, senior lecturer of the Administrative and Criminal Law Department, Povolzhsky Institute of Management named after P.A. Stolypin, Branch of the Russian Presidential Academy of National Economy and Public Administration

\section{SPECIFICS \\ OF OVERCOMING GAPS IN THE PUBLIC SECTORS \\ OF RUSSIAN LAW}

The concept and essence of gaps in the Russian law are analyzed. Peculiarities of overcoming gaps in the public sectors of Russian law, in particular, in criminal and criminal procedure law are considered. Examples of overcoming gaps in criminal law in recent years are given.

Key words and word-combinations: gaps in law, criminal law, improvement of legislation.
Е.Ю. Яноъич, старший преподаватель кафедри административного и уголовного права Поволжского института управления имени П.А. Стольпина - филиала Российской академии народного хозяйства и государственной службб nри Президенте РФ (email: yanichkate@yandex.ru)

\section{ОСОБЕННОСТИ ПРЕОАОАЕНИЯ ПРОБЕАОВ В ПУБАИЧНЫХ ОТРАС АЯ РОССИЙСКОГО ПРАВА}

Аннотация. Анализируются понятие и сущность пробелов в отечественном праве. Рассматриваются особенности преодоления пробелов в публичных отраслях российского права, в частности, в уголовном и уголовно-процессуальном. Приводятся примеры преодоления пробелов в уголовном праве за последние годы.

Ключевые слова и словосочетания: пробелы в праве, уголовное право, совершенствование законодательства.

B В юридической науке под пробелом в праве принято понимать отсутствие в Аействующем законодательстве нормативных предписаний в отношении жизненных обстоятельств, находящихся в сфере правового регулирования и требующих юридического воздействия [1, с. 180]. Существование пробелов в законодательстве присуще бой правовой системе. Это обусловцено как объективными, так и субъективными причинами - недосмотром законодателя, ошибками и неточностями юридической техники. Аинамика развития обществен- 
ных отношений требует постоянного обновления правового регулирования, но законодательные органы не в состоянии мгновенно на нее реагировать.

В праве различают понятия «преодоление» и «устранение» пробелов в законодательстве. Цель настоящей публикации - рассмотрение проблем преодоления пробелов в публичных отраслях российского права, прежде всего в уголовном и уголовно-процессуальном праве. Выбор данных отраслей права не случаен: уголовное право закрепляет преступность и наказуемость деяний, регулирует вопросы привлечения к уголовной ответственности и освобождения от нее, а также закреппяет конкретные составы преступлений, наказуемых уголовным законом. Только в рамках уголовного судопроизводства можно доказать вину мица в инкриминируемом преступмении и назначить ему уголовное наказание. В связи с этим анализ имеющихся в данной сфере пробелов и неточностей законодательстве является объяснимым и целесообразным.

В настояшее время в юридической практике признается Аишь один способ устранения пробелов в законодательстве, а именно принятие нового нормативного акта, содержащего необходимые нормы. Преодоление пробелов возможно с помощью применения аналогии закона и анамогии права. Особо отметим, что применение права по аналогии - это не разрешение дела по усмотрению правоприменителя. Применение аналогии происходит в соответствии с волей государства. С помошью использования аналогии орган, применяющий нормы права, не устраняет имеющийся пробел в праве, а мишь преодолевает его. ОАнако подобная аналогия может применяться далеко не во всех отраслях российского права. Например, в уголовном праве она прямо запрещена положениями ч. 2 ст. 3 УК РФ. Ее применение является прямым нарушением принџипа законности, закрепленного данной статьей.

В чем главная причина запрета аналогии в Аанной отрасли права? Если преАположить возможность применения аналогии в уголовном праве, возникнет опасность привлечения к уголовной ответственности миџа за деяние, которое не содержится в УК РФ, хоть и явмяется сходным. Согласно ст. 8 УК РФ основанием уголовной ответственности является совершение деяния, содержащего все признаки состава преступления, предусмотренного настояшим Кодексом. Һюбое отступление от этого требования - грубейшее нарушение закона. Тем не менее в истории развития уголовного законодательства существуют примеры применения уголовного закона по аналогии. В частности, угон воздушного и водного судна как самостоятельная уголовно-правовая норма впервые появицась в российском законодательстве в 1965 г. Ао этого уголовный закон позволял квалифиџировать действия виновных по аналогии: как хулиганство, самоуправство или хищение государственного или общественного имущества [2, с. 4] .

Примером удачного восполнения пробела в уголовном законодательстве, по нашему мнению, является введение в действие в 2015 г. ст. 234.1 УК РФ «Незаконный оборот новых потенциально опасных психоактивных веществ». Аанные вещества («спайсы», «соли» и т.п.) наносят непоправимый вреА здоровью Аюдей, однако до введения данной статьи привлечь к ответственности изготовитемей и торговцев подобными вешествами не представлялось возможным. Это объяснялось тем, что УК РФ традиционно содержал нормы об ответственности за незаконный оборот наркотических, психотропных и 
ядовитых веществ, в перечень которых ныне запрещенные психоактивные вещества не входили. Эффективным стало и введение в действие положений ст. 110.1 УК РФ «Склонение к совершению самоубийства ици содействие совершению самоубийства», что дает возможность привцечения к уголовной

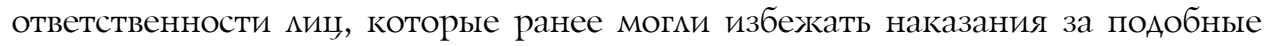
Аеяния. Аиспозиция ч. 1 ст. 110 УК РФ «Аоведение до самоубийства» содержит исчерпывающий перечень способов Аоведения киџа Ао самоубийства мибо до покушения на самоубийство - угрозы, жкестокое обращение или систематическое унижение человеческого достоинства потерпевшего. Остальные

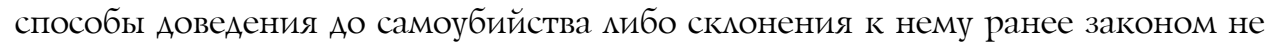
наказывались; не выделялось и само понятие склонения к самоубийству. В ч. 1 ст. 110.1 УК РФ Аанный пробел удачно восполнен - уголовно наказуемыми стали такие способы совершения преступления, как уговоры, предложения, подкуп, обман, содействие совершению самоубийства советами, указаниями, преАоставлением информации, среАств или орудий совершения самоубийства мибо устранением препятствий к его совершению или обещанием скрыть средства или орудия совершения самоубийства. Введение в действие положений ст. 110.2 УК РФ «Организаџия деятельности, направленной на побуждение к совершению самоубийства путем» позволило начать эффективную борьбу с деятельностью печально известных в Интернете «групп смерти».

Несмотря на приведенные успешные примеры восполнения пробелов в угомовном законодательстве, некоторые вопросы остаются открытыми. Согласимся с точкой зрения Э.В. Густовой о том, что неАостаточно четкой является формумировка Аиспозиции ч. 1 ст. 151.2 УК РФ «Вовлечение несовершеннолетнего в совершение Аействий, представцяющих опасность Аля жкизни несовершеннолетнего». Круг Аействий, представцяющих опасность Аля жизни несовершеннолетнего, может быть слишком широк Аля однозначного определения преступного деяния. Возможкно, следует дать пояснение в примечании к данной статье [3] .

Кроме того, необходимо дополнить нормы, предусматривающие уголовную ответственность за рял преступлений, связанных с вовцечением несовершеннолетних в совершение антиобщественных действий (потребление наркотических средств и психотропных веществ, занятие проституцией), указанием на 18-летний возраст субъекта данного преступления [4]. В настоящее время ст. 20 УК РФ преАусматривает только общий возраст привлечения миџа к ответственности - 16 мет, и возможность снижения его до 14 мет за исчерпывающий перечень преступлений, общественную опасность и наказуемость которых миџо, не имеющие отставания в психическом развитии, способно осознавать в Аанном возрасте.

Рассмотрим подробнее еще одну илмюстрацию пробела в уголовном законе законодательное закрепление института необходимой обороны. При решении крайне важного практического вопроса о наличии признаков превышения преАелов необходимой обороны не рекомендуется автоматически исходить из требования о соответствии орудий и способов защиты от посягательства [5] .

В ст. 37 УК РФ, закрепляющей Аанный правовой институт, не упоминается о случаях обороны против мица, находящегося в состоянии алкогольного и 
наркотического опьянения. Этому аспекту не удемяет внимания и Пкенум Верховного Суда РФ в постановлении «О применении судами законодательства о необходимой обороне и причинении вреда при задержании мица, совершившего преступление» [6]. ОАнако на практике большинство случаев превышения предемов необходимой обороны происходит именно в ситуации, когда потерпевший вынужден обороняться против посягатемя, находящегося в нетрезвом состоянии, с применением различных бытовых предметов, например, кухонного ножа. Такая оборона может в ряде случаев привести к смерти посягателя, а обороняющееся киџо из жертвы преврашается в преступника и предстает переА судом по обвинению в убийстве с превышением пределов необходимой обороны. Чтобы избежать подобной несправедливой практики, целесообразно, на наш взгляА, внести уточнения в формулировку ст. 37 УК РФ, в частности, закрепить в ней возможность смягчения мибо освобожАения от уголовной ответственности в случаях обороны против киџа в состоянии алкогольного мибо наркотического опьянения.

По нашему мнению, имеется некоторая неточность при формулировке таких форм хищения, как присвоение и растрата, содержащаяся в ст. 160 УК РФ. Согласно ч. 1 данной статьи присвоение и растрата понимаются как синонимы - «присвоение или растрата, то есть хищение чужого имущества, вверенного виновному». ОАнако присвоение и растрата - не тождественные формы хищения, что подтверждается положениями постановления Пиенума Верховного Суда РФ от 30 ноября 2017 г. «О судебной практике по делам о мошенничестве, присвоении и растрате». Согласно постановлению, присвоение - это безвозмездное противоправное обращение киџом вверенного ему имущества в свою пользу, а растрата - это противоправное действие кица, в корыстных цемях истратившего вверенное имушество, в частности, путем передачи Аругим кицам [7]. Преодоление данного пробела на практике в настоящее время происходит с помощью указанного постановления Пценума Верховного Суда РФ. Устранить этот пробел позволит введение в рассматриваемую уголовно-правовую норму примечания, в котором четко будут разграничены понятия присвоения и растраты.

При обращении к уголовно-процессуальному праву также приходится констатировать ряд пробелов и неточностей в законодательстве. Например, в нем отсутствует понятие правового статуса помощника судьи, сравнительно нового участника уголовного процесса. Квалификационные требования к помощнику судьи содержатся в ряде иных нормативных актов, в частности, в типовых должностных регламентах помошника председателя суда (судьи) верховного суда республики, краевого и областного судов, суда города федерального значения, судов автономной области и автономного округа, окружного (флотского) военного суда, районного суда и гарнизонного военного суда. На наш взгляА, цемесообразным бымо бы закрепление соответствующих норм в УПК РФ.

Преодоление пробелов в уголовно-процессуальном праве представцяется несколько более мегкой задачей, постольку в данной отрасли вполне возможно применение аналогии закона. Она допустима, если возникает ситуация, прямо не регулируемая нормами УПК РФ. В этом случае на практике вполне возмож-

136 Bulletin of the Volga Region Institute of Administration • 2019. Vol. 19. № 2 
но применить норму права, которая разрешает наиболее сходный случай. Например, ч. 2 ст. 189 УПК РФ прямо запрещает следователю при допросе задавать допрашиваемому мицу наводящие вопросы, то есть вопросы, содержащие в себе ответ. ОАнако Амя судьи и прокурора - государственного обвинителя закон не содержит такого запрета, что, однако, не означает, что эти участники уголовного проџесса вправе задавать наводящие вопросы. Аанный пример является иццюстраџией применения уголовно-проџессуального закона по аналогии.

Аналогия применяется и в уголовно-исполнительном праве. Ее использование не запрещено УИК РФ. В частности, в перечень действий, которые расцениваются как злостное нарушение порядка отбывания мишения свободы, ст. 116 УИК РФ вкцючено употребление осужденными наркотических среАств или психотропных веществ, однако в статье не упоминаются новые потенциально опасные психоактивные вещества, то есть «спайсы», «соли» и т.п. Не считаются данные вещества запрещенными и в ином правовом документе, действующем в сфере исполнения наказаний - Правилах внутреннего распорядка исправительных учреждений [9]. В перечне вешей и преАметов, за-

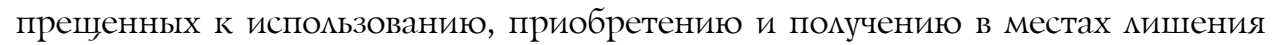
свободы фигурируют толыко наркотические средства, психотропные токсические и сильнодействующие вещества и их аналоги. Приведенные положения нормативных актов, разумеется, не означают разрешения дия осужденных употребцять так называемые «соли» и «спайсы». Запрет на их использование аналогичен запрету на указанные наркотические, психотропные и сильнодействующие вещества, а осужденные, употребляющие их, подвергаются мерам Аисџиплинарной ответственности в соответствии со ст. 116 УИК РФ.

В науке традиционно уделяется внимание способам устранения пробелов в законодательстве с помощью судебной практики, позитивно оценивается деятельность высших российских судов, которые обобщают практику и в своей деятельности исходят из приоритета базовых, основных законов.

Правоприменителю при возникновении затруднений в проџессе применения закона в практической деятельности следует порекомендовать к использованию акты толкования права. Они, не явцяясь нормативными правовыми актами, несут в себе элемент обязательности, издаются правомочными и авторитетными органами, а также имеют под собой тщательно подготовленное научное обоснование толкуемой нормы [10, с. 7]. Примером подобных интерпретационных актов служат постановцения Пценума Верховного Суда РФ по различным категориям уголовных дем. Так, благодаря постановлению Пиенума Верховного Суда РФ по делам об убийстве можно уяснить содержание следующих понятий: убийство с особой жестокостью, убийство, сопряженное с похищением, убийство из корыстных побуждений и т.п. Кроме того, данные акты содержат важные рекомендации для правоприменителя о разграничении смежных составов преступлений и о типичных ошибках в квацификации Аеяний. Подобные разъяснения Пиенума Верховного Суда РФ Аействуют и в иных публичных отраслях права.

Существование пробелов в уголовном и уголовно-процессуальном законе неизбежнн приводит к ошибкам в правоприменении, а в итоге - к ущемлению прав и свобод граждан. Наличие пробелов свидетельствует о неполноте 
и неточности юридической регламентации, что крайне нежелательно в таких строго формализованных отраслях российского права. Неясность при формулировании норм закона вмечет возможность произвольнойтрактовки норм закона и, как следствие, возможное нарушение законности при производстве по уголовному деку.

Таким образом, одним из приоритетных направлений совершенствования уголовно и уголовно-проџессуального закона является восполнение существующих в нем пробелов. Следует стремиться к тому, чтобы в проџессе применения права пробелов было как можно меньше, а добиться этого можно своевременным правотворчеством [11]. Законодатель должен оперативно принимать необходимый закон или Аругой нормативный правовой акт, однако в современной жизни это не всегда возможно, поскольку принятие нового закона или нормативного акта занимает определенное время, требует специальных процедур, затрат и многого другого. Следовательно, важнейшими способами, с помощью которых осушествляется преодоление пробелов в праве, остаются аналогия права и аналогия закона.

\section{Библиографический список}

1. Общая теория государства и права: учебник / под ред. С.Ю. Наумова, А.С. Мордовца, Т.В. Касаевой. Саратов, 2018.

2. Пантелеев В.П. Угон автомототранспортных средств (уголовно-правовые и криминалистические вопросы): учебное пособие. Караганда, 1982.

3. Густова Э.В. Новеллы уголовного законодательства: проблемы конструирования и применения // Журнал российского права. 2018. № 11. С. 129-137.

4. Кауфман М.A. Пробелы в уголовном праве и способы их преодоления: автореф. дис. ... д-ра юрид. наук. М., 2009.

5. Янович Е.Ю., Портнов А.В. Убийство, совершенное при превышении пределов необходимой обороны: актуальные вопросы теории и практики // Саратовская область: традиции, инновации, стратегии лидерства: сборник научных трудов Всероссийской научно-практической конференции студентов, магистрантов, аспирантов, посвященной 80-летию Саратовской области: в 2 ч. Саратов, 2016. С. 157-158.

6. О применении судами законодательства о необходимой обороне и причинении вреда при задержании лица, совершившего преступление: постановление Пленума Верховного Суда РФ от 27 сент. 2012 г. № 19 // Российская газета. 2012. № 227 (5900).

7. О судебной практике по делам о мошенничестве, присвоении и растрате: постановление Пленума Верховного Суда РФ от 30 нояб. 2017 г. № 48 // Российская газета. 2017. № 280 (7446).

8. Об утверждении типовых должностных регламентов помощника председателя суда (судьи) верховного суда республики, краевого и областного судов, суда города федерального значения, судов автономной области и автономного округа, окружного (флотского) военного суда, районного суда и гарнизонного военного суда: приказ Судебного департамента при Верховном Суде РФ от 6 дек. 2010 г. № 272. URL: https://www.garant.ru/products/ipo/prime/doc/1699054/

9. Об утверждении Правил внутреннего распорядка исправительных учреждений: приказ Минюста России от 16 дек. 2016 г. № 295 (в ред. от 27 марта 2019 г.). URL: http://www. consultant.ru/document/cons_doc_LAW_210064/

10. Черепенникова Ю. $\bar{C}$. Пробелы в Особенной части Уголовного кодекса Российской Федерации и способы их восполнения: автореф. дис. ... канд. юрид. наук. М., 2010.

11. Попова Л.Е. Толкование норм и восполнение их пробелов // Закон и жизнь. 2018. № 4. C. 13-19. 